This is an author produced version of a paper published in Acta Agriculturae Scandinavica, Section B - Soil \& Plant Science. This paper has been peer-reviewed but may not include the final publisher proof-corrections or pagination.

Citation for the published paper:

Båth, Birgitta \& Otabbong, Erasmus. (2013) Availability of phosphorus in greenhouse cropping systems with tomatoes - influence of soil and citric acid. Acta Agriculturae Scandinavica, Section B - Soil \&Plant Science. Volume: 63, Number: 6, pp 483-488.

http://dx.doi.org/10.1080/09064710.2013.804115.

Access to the published version may require journal subscription. Published with permission from: Taylor \& Francis.

Epsilon Open Archive http://epsilon.slu.se 


\title{
Availability of phosphorus in greenhouse cropping systems with tomatoes - influence of soil and citric acid -
}

\author{
BIRGITTA BÅTH ${ }^{1 *}$, ERASMUS OTABBONG ${ }^{2}$ \\ ${ }^{1}$ SLU, Department of Crop Production Ecology, Box 7043, SE-750 07 Uppsala, Sweden \\ ${ }^{2} S L U$, Department of Soil and Environment, Box 7014, SE-750 07 Uppsala, Sweden \\ * corresponding author: mail:birgitta.bath@vpe.slu.se, phone: +46 18672310
}

\begin{abstract}
Analyses of plant sap from organic greenhouse tomato crops show that the levels of phosphorus (P) are frequently low, despite the fact that soil analyses indicate $\mathrm{P}$ status in the soil to be good. In the present study, two soils (A and $\mathrm{B}$ ) with a pH just over 6 and a high total content of $\mathrm{N}$ and $\mathrm{P}$ were investigated with respect to release of $\mathrm{P}$ and uptake in a tomato crop. The fertilisers primarily used on soil A was silage and bloodmeal, and on soil B Vinasse and blood meal. An incubation experiment showed that the release of $\mathrm{P}$ per unit time was greater from soil A than soil B. This difference between the two soils may be due to lower soil organic matter concentration, with less $\mathrm{P}$ sorbed by $\mathrm{Al}$ and $\mathrm{Fe}$ on soil $\mathrm{A}$, and a fertiliser regime which favours a high concentration of dissolved organic carbon in this soil. Tomato plants grown for 10 weeks in the soils had greater DW production, total uptake of $\mathrm{P}$ and concentration of $\mathrm{P}$ in the leaves on soil A than on soil B. Addition of citric acid to the soils in order to mobilise $\mathrm{P}$ increased plant yield and uptake of $\mathrm{N}$ and $\mathrm{P}$ on soil A. Despite the increased growth, the concentration of $\mathrm{P}$ in plant leaves increased and the $\mathrm{N}$ concentration was unchanged. On soil B addition of citric acid decreased Zn uptake in the tomato plants despite good availability, resulting in a lower concentration of this micronutrient in the leaves. The plants on soil A maintained their concentrations of all micronutrients analysed, but the ratio of $\mathrm{P}$ to micronutrients increased. Thus for commercial organic tomato growers, adding citric acid with the irrigation water offers a possibility to increase P availability.
\end{abstract}

Keywords: Phosphorus, Nitrogen, Micronutrients, Tomato crop, Solanum lycopersicum Mill., Citric acid 


\section{Introduction}

For the past ten years, a participatory research group in central Sweden has been working on issues relating to organic production of greenhouse tomatoes. An important issue for the growers in the group is to have a fertilisation strategy that prevents nutrient deficiency developing in the crop. Analyses of plant sap from existing commercial crops show that the levels of phosphorus (P) are frequently low (Magnusson et al., 2010), despite the fact that soil analyses indicate $\mathrm{P}$ status in the soil to be very good.

Phosphorus can be easily fixed in soils, primarily by sorption to mineral surfaces and soil organic matter (SOM) and by ionic association between $\mathrm{P}$ and iron (Fe), aluminium (Al) and calcium (Ca). A study by Ohno et al. (2007) showed that soils with high levels of SOM tended to have less $\mathrm{P}$ in solution than soils with lower levels of organic matter. The higher SOM levels were associated with higher levels of oxalate-extractable $\mathrm{Fe}$ and $\mathrm{Al}$, and therefore higher P sorption capacity and lower sorption site occupancy. Zhang et al. (2005) suggested that the correlation between SOM and $\mathrm{P}$ sorption is the result of $\mathrm{P}$ sorption by $\mathrm{Al}$ and $\mathrm{Fe}$ associated with organic matter.

When soils are deficient in P, plants exude low-molecular-weight organic acids (LOAs) which can mobilise P. Therefore, a strategy to increase $\mathrm{P}$ availability can be to add LOAs to the growing medium. LOAs increase $\mathrm{P}$ availability primarily by desorption and solubilisation mechanisms. Desorption of $\mathrm{P}$ by addition of LOA decreases in the order tricarboxylic acid (i.e. citric) $>$ dicarboxylic acid (i.e. malic, tartaric, oxalic) > monocarboxylic acid (i.e. acetic, formic, lactic) (Bolan et al., 1994; Oburger et al., 2011). Solubilisation is achieved by formation of organic-metal complexes (chelate) between LOAs and ions associated with P (Bolan et al., 1994; Hariprasad \& Niranjana, 2009). The complex formation of LOAs depends on the stability constant for metal ions, which in turn depends on the number of -COOH ions and the solubility factor (pKa), with e.g. a tricarboxylic acid such as citric acid being more effective than dicarboxylic and monocarboxylic acids.

Another factor that may influence $\mathrm{P}$ availability to plants is fertilisation regime. Studies by Ohono \& Crannell (1996) and Ohono et al. (2005) have shown that use of organic amendments such as animal and green manure can increase soil $\mathrm{P}$ availability, animal manure probably having a more long-term effect than green manure. In contrast, a very stable organic material such as sphagnum peat moss has little effect on $\mathrm{P}$ accumulation in plants, according to Barker (2012).

Availability of $\mathrm{P}$ also affects the availability of other plant nutrients. Phosphorus deficiency can give rise to nitrogen $(\mathrm{N})$ deficiency through disruption of protein synthesis in the plant (Jeschke et al., 1997; de Groot et al., 2003). Formation of organic-metal complexes (chelates) increases the plant availability of micronutrients such as Fe, zinc (Zn), manganese (Mn) and copper $(\mathrm{Cu})$, but at the same time high $\mathrm{P}$ levels can cause deficiency of micronutrients through antagonism during uptake in the plant (Epstein \& Bloom, 2005). 
The aim of the present study was to examine the effects of adding citric acid to the growing medium on $\mathrm{P}$ availability to a greenhouse-grown tomato crop. The soils and greenhouse-grown tomato plants were investigated with respect to:

- Release and uptake of $\mathrm{P}$ from soils with different chemical composition and fertilisation strategy

- The effects of adding citric acid with the irrigation water applied to the soils on: i) yield, and ii) uptake and concentrations of $\mathrm{P}, \mathrm{N}, \mathrm{Fe}, \mathrm{Mn}, \mathrm{Zn}$ and $\mathrm{Cu}$.

\section{Materials and methods}

The study was based on two soils (A and B) taken from sites where organic tomato production had been carried out for a long time. The fertiliser used for soil A was based on farmyard manure, silage and bloodmeal, while the fertiliser used for soil B was based on Vinasse, a by-product from the yeast industry that is high in $\mathrm{N}$ and $\mathrm{K}$ and low in $\mathrm{P}$ (Ekoväx, Slättegård), Kalimagnesia (a potassium-magnesium fertiliser) and blood meal.

The experiments on soils A and B were carried out in 2008 (year 1) and 2009 (year 2). In year 1, an incubation experiment was carried out without plants and a greenhouse experiment with tomatoes. In year 2, another greenhouse experiment was carried out on tomatoes, but in this case citric acid was added with the irrigation water in one of the two treatments per soil.

\section{Characterisation of greenhouse soils}

Soil samples were taken in four beds at the two commercial sites at fixed points $0.2 \mathrm{~m}$ from the plants (surface soil was scraped away before sampling) to a depth of $0.3 \mathrm{~m}$, with 10 sampling per bed. Each bed represented one block in the experiments. Soil A consisted of $17 \%$ clay, $9 \%$ silt, $66 \%$ sand and $16 \%$ gravel and had an organic matter content of $16 \%$ $=124 \%$. Soil B consisted of 13\% clay, $28 \%$ silt, $57 \%$ sand $2 \%$ gravel and had an organic matter content of 23\%. The high levels of soil organic matter (SOM) content reflect previous organic matter amendments.

The total content of $\mathrm{N}$ and $\mathrm{P}$ was high in both soils (Table I). However, the concentration of N, P, Mn and Zn was higher in soil B (Mn and Zn were nearly twofold higher than in soil A), while the concentration of $\mathrm{Cu}$ and Fe was higher in soil A. The $\mathrm{pH}$ of both soils was just over 6, which was maintained throughout the experiment.

Table I. Chemical composition (two-year means) of greenhouse soils A and B, which were taken from sites of commercial organic tomato production in Sweden.

\begin{tabular}{lccccccc}
\hline & $\underline{\mathrm{N}}$ & $\underline{\mathrm{P}}$ & $\underline{\mathrm{Fe}}$ & $\underline{\mathrm{Zn}}$ & $\frac{\mathrm{Mn}}{\mathrm{mgkg}^{-1}}$ & $\underline{\mathrm{Cu}}$ & $\begin{array}{c}\mathrm{pH} \\
\text { Soil }\end{array}$ \\
\hline A & 0.62 & 0.26 & 1.23 & 62.4 & 272 & 26.3 & 6.2 \\
B & 1.08 & 0.40 & 0.85 & 118,0 & 538 & 19.2 & 6.4 \\
\hline
\end{tabular}

The results of P fractionation according to Hedley et al. (1982) with some modifications (Otabbong \& Persson, 1994) are shown in Table II. The pH in both soils was below the threshold at which $\mathrm{Al}$ and Fe dominate $\mathrm{P}$ sorption reactions (pH 8) (Tisdale et al., 1999). The $\mathrm{P}$ sorption capacity is often assumed to equal the sum of oxalate-extractable $\mathrm{Al}$ and $\mathrm{Fe}$ in low pH and non-calcareous soils (Zhang et al., 2005). In the present study oxalate-P was $1501 \mathrm{mg}$ 
$\mathrm{kg}^{-1} \mathrm{DM}$ soil in soil A and $2252 \mathrm{mg} \mathrm{kg}^{-1} \mathrm{DM}$ in soil B. In soil A, the concentration of organically bound P was $1106 \mathrm{mg} \mathrm{kg}^{-1} \mathrm{DM}$ soil ( 38\%), while in soil B the corresponding value was $1828 \mathrm{mg}(\sim 45 \%)$.

Table II. Soil P disposition in soil samples from greenhouse soils A and B, which were taken from sites of commercial organic tomato production in Sweden. The fertilisation regime was based on farmyard manure, silage and bloodmeal on soil A and Vinasse, Kalimagnesia and bloodmeal on soil B.

\begin{tabular}{|c|c|c|c|c|c|c|c|c|}
\hline \multirow[b]{2}{*}{ Soil } & \multirow{2}{*}{$\frac{\text { Soluble P }}{\text { Total }}$} & \multicolumn{2}{|c|}{ Al-P } & \multicolumn{2}{|c|}{$\underline{\mathrm{Fe}-\mathrm{P}}$} & \multirow{2}{*}{$\frac{\text { Ca-P }}{\text { Total }}$} & \multirow{2}{*}{$\frac{\text { Mineral P }}{\text { Total }}$} & \multirow[t]{2}{*}{ Total P } \\
\hline & & Total & Organic & $\begin{array}{r}\text { Total } \\
\mathrm{mg}\end{array}$ & $\begin{array}{l}\text { Organic } \\
\text { M soil }\end{array}$ & & & \\
\hline A & 151 & 948 & 761 & 553 & 345 & 277 & 964 & 2893 \\
\hline B & 86 & 1072 & 930 & 1180 & 898 & 441 & 1282 & 4061 \\
\hline
\end{tabular}

\section{Incubation experiment}

The release of $\mathrm{P}$ was monitored for 12 weeks in a dark climate chamber kept at a temperature of $20^{\circ} \mathrm{C}$. The soil samples (300 g DM of soil A and $200 \mathrm{~g} \mathrm{DM}$ of soil B) were placed in 1-L pots without lids. Soil A contained $0.9 \mathrm{~g}$ total P and soil B $0.8 \mathrm{~g}$ total P. Distilled water was then added corresponding to the equivalent of $40 \%$ of water-holding capacity (WHC). Additional distilled water was added once a week to bring the weight back to the original level. The experiment included four replicates per soil and samples were taken at the start and then every two weeks (in week 0, 2, 4, 6, 8, 10 and 12). On each sampling occasion all soil in the pots was removed and frozen.

\section{Greenhouse experiments}

The soil from the cultures was collected and placed in boxes $(0.4 \mathrm{~m} \times 0.4 \mathrm{~m} \times 0.5 \mathrm{~m})$ with drainage holes in the base. Distilled water was then added corresponding to $50 \%$ (year 1 ) and $40 \%$ (year 2) of WHC. The amounts of fresh (FW) and dry (DW) soil, $\mathrm{N}$ and P added to the boxes with the soil are shown in Table III.

Table III. Total amounts of plant fresh (FW) and dry (DW) weight produced on soil A and B and of $\mathrm{N}$ and $\mathrm{P}$ added with the soil in greenhouse experiments on tomatoes in years 1 and 2 . Soils A and B were taken from sites of commercial organic tomato production in Sweden.

\begin{tabular}{lcccccccc}
\hline & \multicolumn{2}{c}{ FW soil $(\mathrm{kg})$} & \multicolumn{2}{c}{ DW soil $(\mathrm{kg})$} & \multicolumn{2}{c}{$\mathrm{N}(\mathrm{g})$} & \multicolumn{2}{c}{$\mathrm{P}(\mathrm{g})$} \\
Soil & Year 1 & Year 2 & Year 1 & Year 2 & Year 1 & Year 2 & Year 1 & Year 2 \\
\hline A & 30 & 35 & 20.1 & 25.2 & 127 & 156 & 54 & 66 \\
B & 32 & 30 & 17.6 & 16.8 & 178 & 193 & 74 & 64 \\
\hline
\end{tabular}

Six-week-old tomato plants of the variety Mecano with two tops, grafted on Maxifort, were planted on 12 March in year 1 . In year 2, single-top plants of the variety Maranello, grafted on Beaufore, were planted on 20 March. The experiments, which were surrounded by border plants to even out climate differences within the greenhouse, had a completely randomised block design with four replicates, the treatments being randomly placed in each block. The temperature in the greenhouse was kept at $\sim 19^{\circ} \mathrm{C}$ during the day and $\sim 16{ }^{\circ} \mathrm{C}$ at night. The plants were pollinated with the aid of bees. No fertilisers were added during the experiment. 
In year 2, citric acid was added with the irrigation water (12 g per $25 \mathrm{~L}$ water) in a mixture with a $\mathrm{pH}$ of 3.6. This $\mathrm{pH}$ value lies within the range normally found in the rhizosphere (Oburger et al., 2011).

The trials were terminated 10 weeks after planting, just before the first harvest, i.e. at a time when the plants are most heavily loaded and nutrient deficiency can easily develop. Yields of FW and DW were recorded for each plant. Leaf samples (three per apex) were taken from every plant; over the first truss, centrally and the upper $20 \mathrm{~cm}$ long leaf. The stem sample consisted of three $10 \mathrm{~cm}$ long pieces including a truss (without fruit), which were taken from the plant base, centre and above the topmost flowering truss. The oldest fruit in each fruit-bearing truss were pooled to one bulk sample. All plant material was dried at $80{ }^{\circ} \mathrm{C}$ and milled before chemical analysis.

\section{Chemical analyses}

Soil texture was characterised by the pipette sedimentation procedure (Ljung, 1987). $\mathrm{pH}$ in air-dried soil was determined in water extracts, 2:1 by volume and organic matter concentration by loss on ignition, corrected for $\mathrm{H}_{2} \mathrm{O}$ in the clay fraction. Before chemical characterisation, the soil was dried at $35{ }^{\circ} \mathrm{C}$ and sieved (2 mm mesh). The total content of $\mathrm{N}$ in soil and plants was analysed on a LECO analyser (CN 2000 USA) according to the Dumas method (Bremner \& Hauk, 1982). Analyses of other plant nutrients were performed using an inductively coupled plasma emission spectrometer (Perkin Elmer Optima 3000 DV) after wet digestion with nitric acid $\left(\mathrm{HNO}_{3}\right)$ in the greenhouse experiment, while available $\mathrm{P}$ in the soil in the incubation experiment was analysed after extraction with acetic acid solution, $\mathrm{pH} 3.4$ (Spurway method). Total nutrient contents were calculated based on DW $\left(105^{\circ} \mathrm{C}\right)$.

\section{Statistical analyses}

In the incubation experiment the variables acetic acid-extractable $\mathrm{P}$ and week were analysed statistically using a fitted linear model comprising the factor soil type. In the greenhouse experiments the analyses aimed to assess the effects of the factor soil type and in year two addition of citric acid on the variables tomato yield and nutrient uptake using a fitted linear model. When significant effects were found, Tukey's method was used to compare treatment means. Means were considered significantly different at the 0.05 level. All statistical analyses were performed using JMP (9).

\section{Results}

Soil P content and tomato crop growth and nutrient uptake, year 1

The content of acetic acid-extractable $\mathrm{P}$ in the incubation experiment was greater in soil $\mathrm{A}$ than soil B ( $p=0.003)$, as can be seen from the slope of the line in Figure 1. In other words, release of $\mathrm{P}$ per unit time was greater from soil A than soil B. 


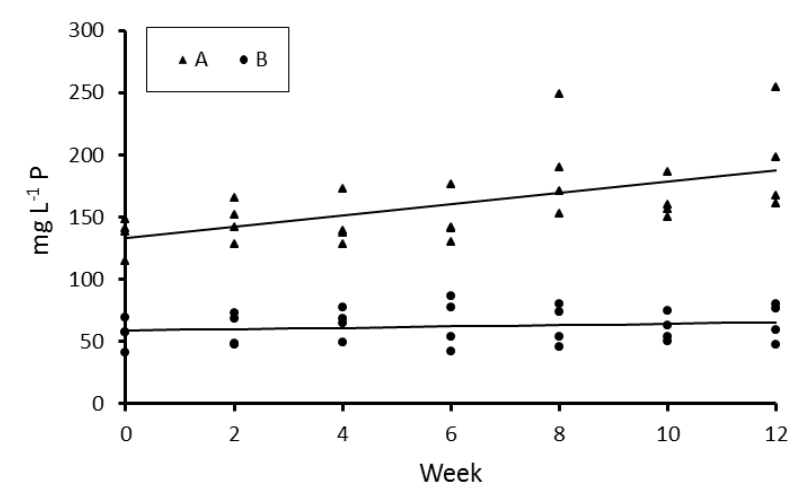

Figure 1. Content of acetic acid-extractable $\mathrm{P}\left(\mathrm{mg} \mathrm{L}^{-1} \mathrm{P}\right)$ in soil A and soil $\mathrm{B}$ during the 12week incubation experiment without plants.

In the greenhouse experiment, DW production at the end of the 10-week experimental period was greater on soil $\mathrm{A}$ than on soil $\mathrm{B}$, as were the total uptake of $\mathrm{P}$ and the concentration of $\mathrm{P}$ in the leaves (Table IV). However, yield of tomatoes was unaffected by soil.

Table IV. Yield of total biomass (DW) and fruits (FW), total P uptake in the plant and concentration of $\mathrm{P}$ in the leaves at the end of a 10 -week greenhouse experiment with tomatoes grown on soils $\mathrm{A}$ and $\mathrm{B}$, which were taken from sites of commercial organic tomato production in Sweden.

\begin{tabular}{|c|c|c|c|c|}
\hline \multirow[b]{3}{*}{ Soil } & \multicolumn{3}{|c|}{ Plant biomass } & \multirow{3}{*}{$\frac{\text { Tomato fruit }}{\text { kg plant }^{-1}}$} \\
\hline & \multirow{2}{*}{ g $_{\text {plant }^{-1}}^{\text {DW }}$} & \multicolumn{2}{|c|}{$\mathrm{P}$} & \\
\hline & & g plant $^{-1}$ & $\%$ in leaf & \\
\hline A & $391 \mathrm{a}$ & $1.7 \mathrm{a}$ & $0.49 a$ & $2.3 a$ \\
\hline B & $315 b$ & $0.8 \mathrm{~b}$ & $0.20 \mathrm{~b}$ & 2.3a \\
\hline
\end{tabular}

\section{Effects of adding citric acid with the irrigation water}

On soil A, addition of citric acid increased the yield of the tomato plants in terms of total DW and fruit yield (FW), and also increased uptake of $\mathrm{N}$ and $\mathrm{P}$ (Table V). Despite the increased growth, the concentration of both $\mathrm{N}$ and $\mathrm{P}$ in the plant leaves was maintained at the same level or even increased. No such differences were observed on soil $\mathrm{B}$. The concentration of $\mathrm{N}$ and $\mathrm{P}$ in the leaves was low overall compared with published values (Bergmann, 1992), except when citric acid was added to soil A.

Table V. Effect of adding citric acid to the irrigation water on yield of total biomass (DW) and fruits (FW), total P uptake in the plant and concentration of $\mathrm{P}$ in the leaves at the end of a 10-week greenhouse experiment with tomatoes. Soils A and B were taken from sites of commercial organic tomato production in Sweden.

\begin{tabular}{|c|c|c|c|c|c|c|c|}
\hline \multirow[b]{3}{*}{ Soil } & \multirow[b]{3}{*}{ Treatment } & \multicolumn{5}{|c|}{ Plant } & \multirow{3}{*}{$\frac{\text { Tomato frui }}{\text { kg }_{\text {plant }}{ }^{-1}}$} \\
\hline & & $\underline{\mathrm{DW}}$ & \multicolumn{2}{|c|}{$\mathrm{N}$} & \multicolumn{2}{|c|}{ P } & \\
\hline & & g $\overline{\text { plant }}^{-1}$ & g plant ${ }^{-1}$ & $\%$ in leaf & g plant $^{-1}$ & $\%$ in leaf & \\
\hline \multirow[t]{2}{*}{ A } & Control & 381c & $10.2 b$ & $3.6 a$ & $1.2 \mathrm{~b}$ & $0.3 \mathrm{~b}$ & $3.1 \mathrm{c}$ \\
\hline & Citric acid & $506 a$ & $12.9 \mathrm{a}$ & $3.6 a$ & $2.1 \mathrm{a}$ & $0.5 a$ & 4.3a \\
\hline \multirow[t]{2}{*}{ B } & Control & 400bc & $8.5 b$ & $2.7 b$ & $0.9 \mathrm{c}$ & $0.1 \mathrm{c}$ & $3.4 \mathrm{bc}$ \\
\hline & Citric acid & $457 \mathrm{ab}$ & $8.5 b$ & $2.2 \mathrm{~b}$ & $1.0 \mathrm{bc}$ & $0.1 \mathrm{c}$ & $4.0 \mathrm{ab}$ \\
\hline
\end{tabular}


As can be seen in Table VI, the concentration of Fe and $\mathrm{Zn}$ in the leaves was adequate (Bergmann, 1992) on both soils, while the concentration of Mn was low on soil A and that of $\mathrm{Cu}$ was low on soil B. Addition of citric acid with the irrigation water decreased Zn uptake in the tomato plants on soil $\mathrm{B}$, while it increased $\mathrm{Cu}$ uptake in the plants on soil A. The concentration of $\mathrm{Zn}$ and $\mathrm{Mn}$ in the leaves decreased on soil $\mathrm{B}$.

Table VI. Effect of adding citric acid to the irrigation water on total P uptake in plants and concentration of micronutrients in the leaves at the end of a 10-week greenhouse experiment with tomatoes. Soils A and B were taken from sites of commercial organic tomato production in Sweden.

\begin{tabular}{|c|c|c|c|c|c|c|c|c|c|}
\hline \multirow[b]{2}{*}{ Soil } & \multirow[b]{2}{*}{ Treatment } & \multicolumn{2}{|c|}{$\mathrm{Cu}$} & \multicolumn{2}{|c|}{$\mathrm{Fe}$} & \multicolumn{2}{|c|}{$\mathrm{Mn}$} & \multicolumn{2}{|c|}{$\underline{\mathrm{Zn}}$} \\
\hline & & mg plant $^{-1}$ & ppm in leaf & mg plant $^{-1}$ & ppm in leaf & mg plant $^{-1}$ & ppm in leaf & mg plant $^{-1}$ & ppm in leaf \\
\hline \multirow[t]{2}{*}{ A } & Control & $2.0 \mathrm{~b}$ & $6.7 \mathrm{a}$ & $20.5 a$ & $110 a$ & $5.5 b$ & $30 \mathrm{bc}$ & $8.9 \mathrm{c}$ & $40 \mathrm{bc}$ \\
\hline & Citric acid & 2.9a & $7.2 \mathrm{a}$ & $25.5 a$ & $100 \mathrm{a}$ & $6.8 b$ & $30 c$ & $11.7 \mathrm{c}$ & $30 c$ \\
\hline \multirow[t]{2}{*}{ B } & Control & $1.2 \mathrm{c}$ & $4.1 \mathrm{~b}$ & $23.8 \mathrm{a}$ & $110 \mathrm{a}$ & 9.3a & $60 \mathrm{a}$ & $20.4 a$ & $90 \mathrm{a}$ \\
\hline & Citric acid & $1.1 \mathrm{c}$ & $3.4 \mathrm{~b}$ & 23.8a & $90 \mathrm{a}$ & $8.5 a$ & $40 \mathrm{~b}$ & $17.1 \mathrm{~b}$ & $60 \mathrm{~b}$ \\
\hline
\end{tabular}

Means within columns followed by different letters are significantly different at $\mathrm{P}<0.05$

The ratio of $\mathrm{P}$ to the micronutrients $\mathrm{Mn}, \mathrm{Fe}, \mathrm{Zn}$ and $\mathrm{Cu}$ in leaves increased with addition of citric acid to the irrigation water to soil A (data not shown). No such tendency was found for soil B.

\section{Discussion}

In the two soils used in this study, SOM and P sorption capacity were higher in soil B than in soil A (Tables II). In addition, $\mathrm{P}$ sorbed by $\mathrm{Al}$ and Fe associated with SOM was higher in soil $\mathrm{B}$ than in soil A (Table II). The release of $\mathrm{P}$ in the incubation experiment and the uptake of $\mathrm{P}$ in the greenhouse experiment in the same year were lower for soil B than soil A (Figure 1, Table IV). This agrees with previous findings by Ohno et al. (2007) that a higher SOM level is associated with higher $\mathrm{P}$ sorption capacity and lower sorption site occupancy. Börling et al. (2001) and Zhang et al. (2005) suggest that this association is the result of P sorbed by Al and Fe associated with SOM.

The greater release of $\mathrm{P}$ from soil $\mathrm{A}$ than soil $\mathrm{B}$ may also be due to differences in fertilisation strategy. The addition of animal manure and silage to soil A probably increased the concentration of dissolved organic carbon (DOC), both directly and via turnover of native SOM, which Ohno et al. (2005) found had a linear relationship with water-soluble P concentration.

Addition of citric acid with the irrigation water in the greenhouse experiment in year 2 increased $\mathrm{P}$ uptake by the tomato plants on soil $\mathrm{A}$ (Table $\mathrm{V}$ ). The concentration of $\mathrm{P}$ in the leaves was rather low $(<0.4 \%)$ on both soils, but increased in soil A when citric acid was added. This means that the availability and uptake of $\mathrm{P}$ increased at a faster rate than biomass growth when citric acid was added to this soil. The efficiency of LOAs in mobilising $\mathrm{P}$ is a function of both the amount of sorption sites and their occupancy and the P concentration in soil solution (Bolan et al., 1994; Guppy et al., 2005; Oburger et al., 2011). In a study with four LOAs and five soils, Oburger et al. (2011) observed the greatest effect at a medium to high amount of sorption sites and occupancy. They also found that in a Cambisol soil, $\mathrm{P}$ solubility seemed to be controlled by $\mathrm{Al}$ and Fe solubility, which in turn was predominantly influenced by the type of LOA. In their case citric acid caused the highest relative solubility. 
Addition of citric acid with the irrigation water in the present study also increased total uptake per plant of $\mathrm{N}$ on soil A (Tables V and VI). The plants on this soil maintained or increased $(\mathrm{Cu})$ their concentrations of all micronutrients, but the ratio of $\mathrm{P}$ to micronutrients increased, i.e. more $\mathrm{P}$ was taken up in relation to $\mathrm{Fe}, \mathrm{Zn}, \mathrm{Mn}$ and $\mathrm{Cu}$. This may be partly due to slow release of these micronutrients compared with the rate of $\mathrm{P}$ release and partly to increased competition for uptake by the plant (Epstein \& Bloom, 2005). On soil B uptake of Zn decreased, despite good availability, resulting in a lower concentration of this micronutrient in the leaves. Similarly, Zhang et al. (2012) found that P application depressed $\mathrm{Zn}$ concentration in winter wheat, while the effect of $\mathrm{P}$ application on $\mathrm{Mn}$, Fe and Cu differed. As the content of DTPA-extractable $\mathrm{Zn}$ in soil was not reduced and the decreased $\mathrm{Zn}$ concentration could not be explained solely by the 'dilution effect', those authors argued that increased P availability in soil decreased Zn uptake by roots and/or Zn translocation from root to shoot.

Overall, the present study showed that for commercial organic tomato growers, adding citric acid with the irrigation water offers a possibility to increase P availability and thus use this limited resource in a more sustainable way.

\section{References}

Barker, A.V. (2012). Plant growth in response to phosphorus fertilizers in acidic soils amended with limestone or organic matter. Communication in Soil Science and Plant Analysis , 43, 1800-1810.

Bergmann, W. (1992). Nutritional disorder of plants: development, visual and analytical diagnosis. New York: G. Fisher.

Bolan, N.S., Naidu, R., Mahimairaja, S. \& Baskaran, S. (1994). Influence of low-molecular-weight organic acids on the solubilization of phosphates. Biology and Fertility of Soils , 18, 311-319.

Börling, K., Otabbong, E. \& Barberis, E. (2001). Phosphorus sorption in relation to soil properties in some cultivated Swedish soils. Nutrient Cycling in Agroecosystems , 59, 39-46.

Bremner, J.M. \& Hauk, R.D. (1982). Advances in methodology for research on nitrogen transformation in soil. In: Stevenson, F.J. (Ed.), Nitrogen in Agricultural soils, American Society of Agronomy, Madison, Wisconsin, pp. 467-502.

de Groot, C.C., Marcelis, L.F.M., van den Boogaard, R., Kaiser, W.M. \& Lambers, H. (2003). Interaction of nitrogen and phosphorus nutrition in determining growth. Plant and Soil , 248, 257-268.

Epstein, E. \& Bloom, A.J. (2005). Nutrition of plants: Principles and perspectives, $2^{\text {nd }}$ edition, Sinauer, Sunderland, Massachusetts, USA.

Guppy, C.N., Menzies, N.W., Moody, P.W. \& Blamey, F.P.C. (2005). Competitive sorption reactions between phosphorus and organic matter in soil: a review. Australian Journal of Soil Research , 43, 189-202.

Hariprasad, P \& Niranjana, S.R. (2009). Isolation and characterization of phosphate solubilizing rhizobacteria to improve plant health of tomato. Plant and Soil , 316, 13-24.

Hedley, M.J., Stewart, J.W.B. \& Chauhan, B.S. (1982). Changes in inorganic soil phosphorus fractions induced by cultivation practices and laboratory incubations. Soil Science American Journal , 46, 970-976.

Jeschke, W.D, Kirkby, E.A., Peuke, A.D., Pate, J.S. \& Hartung, W. (1997). Effects of P on assimilation and transport of nitrate in intact plants of castor bean (Ricinus communis L.). Journal of Experimental Botany, 48, 75-91.

Ljung, G. (1987). Mekanisk analys - Beskrivning av en rationell metod för jordartsbestämning. In Avdelningen för Lantbrukets Hydroteknik, Avdelningsmeddelande 87. SLU, Uppsala. (InSwedish)

Magnusson, M., Ögren, E. \& Homman,K. (2010). Samband mellan odlingsförutsättningar, växtnäring och skörderesultat samt utarbetande av riktvärden för jordanalys $i$ ekologisk tomatodling. Rapport 4, LänsstyrelsenVästmanland, Sweden. (In Swedish)

Oburger, E., Jones, D.L. \& Wenzel, W.W. (2011). Phosphorus saturation and pH differentially regulate the efficiency of organic acid anion-mediated P solubilisation mechanisms in soil. Plant and Soil , 341, 363-382.

Ohno, T. \& Crannell, B.S. (1996). Green and animal-derived effects dissolved organic matter effects on phosphorus sorption. Journal of Environmental Quality , 25, 1137-1143. 
Ohno, T., Griffin, T.S., Liebman, M. \& Porter, G.A. (2005). Chemical characterization of soil phosphorus and organic matter in different cropping systems in Maine, U.S.A. Agricultural Ecosystems and Environment , $105,625-634$.

Ohno, T., Hoskins, B.R. \& Erich, M.S. (2007). Soil organic matter effects on plant available and water soluble phosphorus. Biology and Fertility of Soils , 43, 683-690.

Otabbong, E. \& Persson, J. (1994). Relative agronomic merit of fused calcium phosphate. III Forms of phosphorus in soils repeatedly cropped in pot experiments. Acta Agriculture Scandinavica Sect. B, Soil and Plant Science , 44, 2-11.

Tisdale, S.L., Havlin, J.L., Beaton, J.D. \& Nelson, W.L. (1999). Soil fertility and fertilizers - an introduction to nutrient management. Sixth edition, Prentice-Hall, Inc.

Zhang, H., Schroder, J.L., Fuhrman, J.K., Basta, N.T., Storm, D.E. \& Payton, M.E. (2005). Path and multiple regression analyses of phosphorus sorption capacity. Soil Science Society American Journal , 69, 96-106.

Zhang, Y.Q., Deng, Y., Chen, R.Y., Cui, Z.L., Chen, X.P., Yost, R., Zhang, F.S. \& Zou, C.Q. (2012). The reduction in zinc concentration of wheat grain upon increased phosphorus fertilization and its mitigation by foliar zinc application. Plant and Soil , 361, 143-152. 